\title{
CUSTOMER CAPITAL AS A KEY FACTOR OF E-COMMERCE MARKET DEVELOPMENT
}

The importance of customer satisfaction has always been crucial to development of every single market in general. E-commerce market has gained importance during the last few years - especially in terms of annual turnover of e-commerce market. This trend is the result of changes in customer behavior. Increasing customer loyalty is one of the keys to business success. Active customer policy is necessary for the development of the market in individual states. The central point of the issue is to find concrete social constructs which can explain customer behavior in recent years. The main objective of the research is to define the area of selected variables which can be regarded as crucial in the process of predicting development of e-commerce market. By using Theory of Planned Behavior (TPB), the dependence of development of e-commerce market on customer capital has been confirmed.

Keywords: Communication, customer capital, e-commerce, B2C market.

\section{Introduction}

The effort of each company and of any market is to guarantee the highest possible level of customer satisfaction [1]. The issue of consumer behavior in relation to possible prediction of the behavior of market development is dealt with by the means of intellectual capital and customer capital in particular, as it is a part of the intellectual capital [2 and 3].

E-commerce market has gained importance during the last few years, especially in terms of annual turnover of e-commerce market of individual states. This trend is important especially when taking into account the fact that the transition to this new way of doing business is associated with a wide range of activities [4, 5 and 6]. Within these activities, there exists a considerable scope for reduction of individual cost elements [7, 8, 9 and 10]. E-commerce market can be divided in terms of direction of the transaction - individual subjects stand on the side of supply or demand [11, 12 and 13]. Timeliness of this research is evident from the number of studies dealing with the analysis of e-commerce market trends on global basis. Dieke et al. from the company WIK Consult GmbH have dealt with the issues of designing and development of initiatives to promote the growth of e-commerce market via better functioning parcel delivery systems [14]. Burkl from the Gfk company addresses in his study the current state of the consumer surroundings in selected countries of European Union (EU) [15].

The main objective of this article is associated with the above defined topics. It is to define the area of selected variables which can be regarded as crucial in the process of predicting development of e-commerce market. It means to carry out analysis of indicators of development of turnover B2C (business to customer) e-commerce market from selected member states of the EU in relation to dependent variables which define the social constructs that may affect customer capital of e-commerce market. The general model called Theory of Planned Behavior (TPB) will be used for verification of the defined area. At present, this model is not used for research of components of intellectual capital.

\section{Material and methods}

TPB is often used as a theoretical basis for prediction of human (social) behavior. TPB is based on the Theory of reasoned action [16 and 17]. Both theories are based on the assumption that individual's intention to perform a specific act of behavior is the result of the determinants of that behavior. The intent is understood as the "expression of the difficulty of performing a specific act of behavior" or the "expression of the effort which

\footnotetext{
* 'Dalibor Gottwald, ${ }^{1}$ Libor Svadlenka, ${ }^{2}$ Hana Pavlisova

${ }^{1}$ Department of Transport Management, Marketing and Logistics, Jan Perner Transport Faculty, University of Pardubice, Czech Republic,

${ }^{2}$ Department of English and American Studies, Faculty of Arts, Palacky University Olomouc, Czech Republic

E-mail: libor.svadlenka@upce.cz
} 
individuals plan to make in order to perform this act of behavior." For the general expression of TPB, it is necessary to define the following areas:

- attitudes towards behavior: the degree of individual's favorable or unfavorable evaluation of performance of a specific act of behavior;

- subjective norms determining the intent: the social pressure perceived in regards to the performance of a specific act of behavior [18].

Over the past few years, the TPB and the Theory of reasoned action were applied in a number of research articles [19, 20, 21 and 22]. Their aim was to predict the future intentions and specific behaviors. Later on, the TPB theory was expanded by the construct of Perceived Behavioral Control, which can be understood as a general attitude of the individual or a society towards the investigated act of behavior [19 and 23]. Now the TPB theory is used as a general theoretical framework for prediction of behavior (Fig. 1).

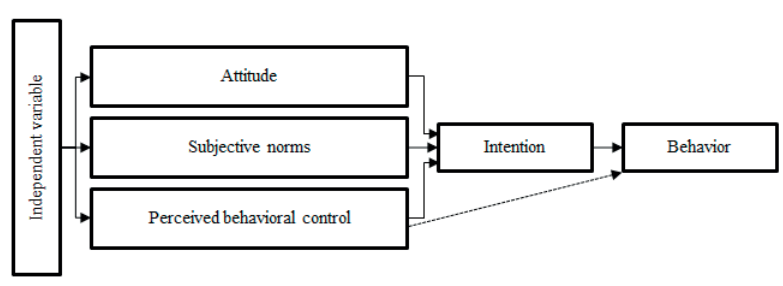

Fig. 1 General model Theory of Planned Behavior Source: [18]
It is clear from the above mentioned model that behavior is determined by the intent, which is constituted by three components. To ensure the maximum relevance of predicted expected behavior, it is necessary to compare the current state of area under consideration with findings from the previous periods of time [24].

Nowadays, TPB is frequently used especially in social sciences, especially in research of predicting the behavior of individuals in terms of health straight behavior [25 and 26].Given the fact that TPB is used to predict the behavior of individuals, it will be necessary to take over a general methodology with an overlap to allow the prediction of the behavior of e-commerce market in selected member states of the EU.

Attitude: Variables which can be considered adequate in regards to compliance with the general TPB model are "Households with internet access at home - percentage of households with at least one member aged 16 to 74 " and "Last internet use: within last 12 months". Using these indicators, it is possible to gain information about society-wide attitudes towards online shopping in individual states. The Internet is an infrastructure of online shopping and the access to Internet can be seen as society's attitude towards a specific act of behavior (online shopping).

Subjective norms: "Annual Net Earnings: single person without children, $50 \%$ of average wage" variable can be understood as a subjective norm for the possibility of online shopping (the higher the society's earnings, the bigger the assumed total turnover of e-commerce market). Also the "Enterprises selling via Internet: all enterprises without financial sector (10 persons employed or more)" variable is relevant, this time for its relation

B2C turnover (bn EUR)

Table 1

\begin{tabular}{|l|c|c|c|c|}
\hline & 2011 & 2012 & 2013 & 2014 \\
\hline United Kingdom & 84.107 & 96.193 & 110.890 & 127.190 \\
\hline France & 37.700 & 45.000 & 51.100 & 13.800 \\
\hline The Netherlands & 10.927 & 11.869 & 12.877 & 5.961 \\
\hline Ireland & 3.040 & 3.800 & 4.600 & 4.368 \\
\hline Belgium & 2.200 & 3.040 & 3.820 & 71.200 \\
\hline Germany & 41.085 & 50.000 & 63.400 & 11.685 \\
\hline Austria & 8.405 & 9.800 & 10.970 & 6.541 \\
\hline Poland & 3.349 & 4.183 & 5.225 & 2.874 \\
\hline Czech Republic & 1.505 & 1.800 & 2.160 & 16.900 \\
\hline Spain & 10.916 & 12.969 & 14.414 & 13.278 \\
\hline Italy & 8.078 & 9.565 & 11.268 & 3.850 \\
\hline Greece & 1.800 & 2.560 & 3.200 & 2.945 \\
\hline Portugal & 2.000 & 2.300 & 2.600 & 9.938 \\
\hline Sweden & 6.418 & 7.221 & 8.622 & 9.886 \\
\hline Denmark & 6.172 & 7.339 & 8.367 & 7.290 \\
\hline Finland & 6.005 & 6.137 & 6.500 & \\
\hline
\end{tabular}

Source: [27]. 
to the number of such companies (the bigger the number of such companies, the bigger the assumed total turnover of e-commerce market). These defined variables comply with the assumptions of the general model, i.e. the possibility, and not the necessity, of performance of a specific act of behavior (online shopping).

Perceived behavioral control: The "Last online purchase in the last three months (percentage of individuals)" variable is a factor informing about the attitude of an individual towards the area under consideration and can also be understood as a factor which directly influences the resulting behavior. It is, however, essential to examine its influence in combination with factors from previous areas.

Due to the nature of the research, one independent variable was determined as a meaningful variable for determining the behavior of e-commerce market, namely B2C e-commerce turnover in 2011, 2012, 2013, and 2014 (Table 1 and Fig. 2).

Data presented in Table 1 reflect the results of research into total turnover of B2C market in years 2011, 2012, 2013, 2014, which were taken from various sources:

- National associations and International associations: Netcomm (Italy), FDIH (Denmark), KAUPPA (Finland), SDH (Sweden), Adigital (Spain), BeCommerce (Belgium), Händlerbund (Germany), FEVAD (France), Apec (Czech Republic), etc.

- Corporate sources: Deloitte, Forrester, Google, Innopay, Social Bakers, I-Research, GfK, Planet Retail, etc.

- Other sources: Digital Hub Development Agency (DHDA), Eurostat, European Central Bank (ECB), National Statistic offices, World Economic Forum, etc.

EU member states which had turnover less than 1 billion EUR were excluded from the research, as well as the European states which are not members of the EU. Defined dependent variables were used to demonstrate their dependence on the independent variable in years 2011-2014. This was done to ensure the maximum relevance of the intention, which is the basis for the expected behavior prediction.

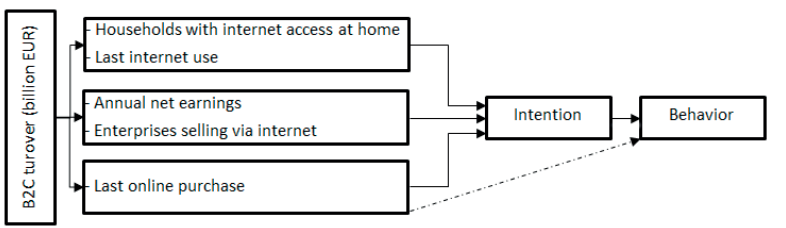

Fig. 2 Modified model Theory of Planned Behavior Source: authors

Pearson's correlation coefficient was used to find the correlation between the independent variable determining the behavior of e-commerce of the market and the defined dependent variables, which are guaranteed by the respective indicators in the three basic categories of TPB model. $r=\frac{\sum(x-\bar{x})(y-\bar{y})}{\sqrt{\sum(x-\bar{x})^{2} \sum(y-\bar{y})^{2}}}$

The final determination of significance of correlation was established on the basis of calculation of $\mathrm{P}$ value with significance level at $5 \%$.

\section{Results and discussion}

The indirect measurement method was used in the research of three components of TPB, i.e. the stated results reflect values taken from studies of international non-governmental organization OECD and the Directorate-General of the European

Measurement of Attitudes

Table 2

\begin{tabular}{|c|c|c|}
\hline ATTITUDE & $\begin{array}{l}\text { Households with internet } \\
\text { access }\end{array}$ & Last internet use \\
\hline \multirow[t]{2}{*}{ Country } & $\mathrm{P}$ value & $\mathrm{P}$ value \\
\hline & Pearson's (r) & Pearson's (r) \\
\hline \multirow[t]{2}{*}{ United Kingdom } & 0.0514 & 0.0205 \\
\hline & 0.9486 & 0.9795 \\
\hline \multirow[t]{2}{*}{ France } & 0.0261 & 0.0120 \\
\hline & 0.9739 & 0.9880 \\
\hline \multirow[t]{2}{*}{ The Netherlands } & 0.0473 & 0.0662 \\
\hline & 0.9527 & 0.9338 \\
\hline \multirow[t]{2}{*}{ Ireland } & 0.1069 & 0.0103 \\
\hline & 0.8931 & 0.9897 \\
\hline \multirow[t]{2}{*}{ Belgium } & 0.0477 & 0.3173 \\
\hline & 0.9523 & 0.6827 \\
\hline \multirow[t]{2}{*}{ Germany } & 0.0043 & 0.0126 \\
\hline & 0.9957 & 0.9874 \\
\hline \multirow[t]{2}{*}{ Austria } & 0.041 & 0.0212 \\
\hline & 0.9599 & 0.9788 \\
\hline \multirow[t]{2}{*}{ Poland } & 0.0076 & 0.1695 \\
\hline & 0.9924 & 0.8305 \\
\hline \multirow[t]{2}{*}{ Czech Republic } & 0.0730 & 0.0096 \\
\hline & 0.9270 & 0.9904 \\
\hline \multirow[t]{2}{*}{ Spain } & 0.0017 & 0.0013 \\
\hline & 0.9983 & 0.9987 \\
\hline \multirow[t]{2}{*}{ Italy } & 0.0410 & 0.0106 \\
\hline & 0.9590 & 0.9894 \\
\hline \multirow[t]{2}{*}{ Greece } & 0.5810 & 0.0083 \\
\hline & 0.9419 & 0.9917 \\
\hline \multirow[t]{2}{*}{ Portugal } & 0.0142 & 0.0739 \\
\hline & 0.9858 & 0.9261 \\
\hline \multirow[t]{2}{*}{ Sweden } & 0.7387 & 0.6542 \\
\hline & -0.2613 & -0.3458 \\
\hline \multirow[t]{2}{*}{ Denmark } & 0.1166 & 0.0250 \\
\hline & 0.8834 & 0.9750 \\
\hline \multirow[t]{2}{*}{ Finland } & 0.1512 & 0.1253 \\
\hline & 0.8488 & 0.8747 \\
\hline
\end{tabular}

Source: authors 
Commission - Eurostat between years 2011 and 2014 (Tables 2, 3 and 4).

Measurement of Subjective norms

Table 3

\begin{tabular}{|c|c|c|}
\hline SUBJECTIVE NORMS & Annual net earnings & $\begin{array}{l}\text { Enterprises selling } \\
\text { via internet }\end{array}$ \\
\hline \multirow[t]{2}{*}{ Country } & P value & $P$ value \\
\hline & Pearson's (r) & Pearson's (r) \\
\hline \multirow[t]{2}{*}{ United Kingdom } & 0.1963 & 0.1158 \\
\hline & 0.8037 & 0.8842 \\
\hline \multirow[t]{2}{*}{ France } & 0.0212 & 0.0489 \\
\hline & 0.9788 & 0.9511 \\
\hline \multirow[t]{2}{*}{ The Netherlands } & 0.0038 & 0.8372 \\
\hline & 0.9962 & 0.1628 \\
\hline \multirow[t]{2}{*}{ Ireland } & 0.0445 & 0.2406 \\
\hline & 0.9555 & 0.7594 \\
\hline \multirow[t]{2}{*}{ Belgium } & 0.0069 & 0.2997 \\
\hline & 0.9931 & -0.7003 \\
\hline \multirow[t]{2}{*}{ Germany } & 0.0229 & 0.1386 \\
\hline & 0.9771 & 0.8614 \\
\hline \multirow[t]{2}{*}{ Austria } & 0.0183 & 0.6700 \\
\hline & 0.9817 & 0.9330 \\
\hline \multirow[t]{2}{*}{ Poland } & 0.0615 & 0.0542 \\
\hline & 0.9385 & 0.9458 \\
\hline \multirow[t]{2}{*}{\begin{tabular}{|l|} 
Czech Republic \\
\end{tabular}} & 0.1050 & 0.2574 \\
\hline & -0.8950 & 0.7426 \\
\hline \multirow[t]{2}{*}{ Spain } & 0.0237 & 0.0436 \\
\hline & 0.9763 & 0.9564 \\
\hline \multirow[t]{2}{*}{ Italy } & 0.0630 & 0.0698 \\
\hline & 0.9370 & 0.9302 \\
\hline \multirow[t]{2}{*}{ Greece } & 0.0189 & 0.2406 \\
\hline & -0.9811 & 0.7594 \\
\hline \multirow[t]{2}{*}{ Portugal } & 0.1439 & 0.2407 \\
\hline & 0.8561 & -0.7593 \\
\hline \multirow[t]{2}{*}{ Sweden } & 0.2165 & 0.6444 \\
\hline & 0.7835 & -0.3556 \\
\hline \multirow[t]{2}{*}{ Denmark } & 0.0388 & 0.9448 \\
\hline & 0.9612 & 0.05521 \\
\hline \multirow[t]{2}{*}{ Finland } & 0.2131 & 0.1759 \\
\hline & 0.7869 & -0.8241 \\
\hline
\end{tabular}

Source: authors

It was found in the research that in the area of "Attitude" (Table 2), the dependence of defined variables on the independent variable (B2C turnover) has been confirmed as statistically significant in both variables ("Households with Internet access" and "Last Internet use") in France, Germany, Austria, Spain, and Italy. Defined dependence has then shown to be significant in at least one of the variables in the United Kingdom, The Netherlands, Ireland, Belgium, Poland, Czech Republic, Greece, Portugal, and Denmark. Results of the statistical testing of the area of "Subjective norms" in Table 3 confirm the dependence of both variables ("Annual net earnings" and "Enterprises selling via Internet”) on the independent variable in France and Spain. Defined dependence has then shown as significant in at least one of the variables in The Netherlands, Ireland, Belgium, Germany, Austria, and Denmark.

From the above tables it is clear that Sweden and Finland (both states are insular states in the north of Europe) do not confirm this dependence in either variable in both areas, which could be used as input data for further research.

Measurement of Perceived behavioral control

Table 4

\begin{tabular}{|c|c|c|}
\hline $\begin{array}{l}\text { PERCEIVED } \\
\text { BEHAVIORAL } \\
\text { CONTROL }\end{array}$ & \multicolumn{2}{|c|}{ Last online purchase } \\
\hline \multirow[t]{2}{*}{ Country } & $P$ value & \multirow{2}{*}{\begin{tabular}{|l} 
Significance \\
of correlation? \\
$(\mathrm{alfa}=\mathbf{0 . 0 5})$
\end{tabular}} \\
\hline & Pearson's (r) & \\
\hline \multirow[t]{2}{*}{ United Kingdom } & 0.0748 & \multirow{2}{*}{ NO } \\
\hline & 0.9252 & \\
\hline \multirow{2}{*}{ France } & 0.0436 & \multirow{2}{*}{ YES } \\
\hline & 0.9564 & \\
\hline \multirow[t]{2}{*}{ The Netherlands } & 0.1102 & \multirow{2}{*}{ NO } \\
\hline & 0.8898 & \\
\hline \multirow[t]{2}{*}{ Ireland } & 0.0797 & \multirow{2}{*}{ NO } \\
\hline & 0.9203 & \\
\hline \multirow[t]{2}{*}{ Belgium } & 0.0431 & \multirow{2}{*}{ YES } \\
\hline & 0.9569 & \\
\hline \multirow[t]{2}{*}{ Germany } & 0.0205 & \multirow{2}{*}{ YES } \\
\hline & 0.9795 & \\
\hline \multirow[t]{2}{*}{ Austria } & 0.1070 & \multirow{2}{*}{ NO } \\
\hline & 0.8930 & \\
\hline \multirow[t]{2}{*}{ Poland } & 0.0160 & \multirow{2}{*}{ YES } \\
\hline & 0.9840 & \\
\hline \multirow[t]{2}{*}{ Czech Republic } & 0.0037 & \multirow{2}{*}{ YES } \\
\hline & 0.9963 & \\
\hline \multirow[t]{2}{*}{ Spain } & 0.0134 & \multirow{2}{*}{ YES } \\
\hline & 0.9866 & \\
\hline \multirow[t]{2}{*}{ Italy } & 0.0272 & \multirow{2}{*}{ YES } \\
\hline & 0.9728 & \\
\hline \multirow[t]{2}{*}{ Greece } & 0.0135 & \multirow{2}{*}{ YES } \\
\hline & 0.9865 & \\
\hline \multirow[t]{2}{*}{ Portugal } & 0.0087 & \multirow{2}{*}{ YES } \\
\hline & 0.9913 & \\
\hline \multirow[t]{2}{*}{ Sweden } & 0.1214 & NO \\
\hline & 0.8786 & NO \\
\hline Denmark & 0.0478 & YES \\
\hline & 0.9522 & IES \\
\hline Finland & 0.0141 & YES \\
\hline & 0.9859 & ILS \\
\hline
\end{tabular}

The research of statistical dependence of the behavior of e-commerce market (B2C turnover) on the variable defining Perceived behavioral control has shown dependence in France, Belgium, Germany, Poland, Czech Republic, Spain, Italy, Greece, Portugal, Denmark, and Finland. 
Only one variable has been established as a dependent variable in Perceived behavioral control. It was due to insufficient data basis of other potential variables which could define this area. On the other hand, there is no requirement for minimal amount of dependent variables defining a given area in the application of TPB [18 and 19].

General result of application of TPB model can be expressed via the correlation of independent variable on the behavior of e-commerce market expressed by the B2C turnover indicator. In Tables 1 and 2, states which show positive correlation in both variables defining the given area of TPB are marked in yellow, while states that show positive correlation at least in one of these variables are marked in green.

Table 3 shows in yellow-green color the states that show positive correlation with the indicator defining behavior of e-commerce market.

Based on the results it can be stated that defined model TPB can be applied to the markets of France and Spain (where correlation was shown in all areas of research), and for Belgium, Germany and Denmark (where positive correlation was shown at least in one variable of the three researched areas of TPB).

The values found in other states can be considered partial results and cannot be applied to prediction of e-commerce market behavior through TPB model. With regards to the fact that the given theory has not been used for prediction of e-commerce market of the EU states so far, these results can be seen as innovative and can be used as a basis for further research of application of this theory on the given area of research.

\section{Conclusions}

The main objective of this article was to highlight the key variables which can be determined as crucial for the prediction of development of e-commerce market from the point of view of the customer capital. It also establishes selected variables which can be understood as relevant in the prediction. TPB is commonly used in social sciences to predict development of a specific phenomenon and in this research was used to define the area of research. TPB was used in this context to innovate the scientific approach towards prediction of e-commerce market behavior.

It can be concluded that TPB has proved to show results in some states. The results can be used in further research, especially in establishment of other variables applicable to the general model of TPB. Another topic for further research would be a closer look at results in a more general context of the currently turbulent e-commerce market.

The results have shown that the influence of customer capital in the selected group of states is statistically significant, and thus the prediction of development of e-commerce market must take into account selected social constructs (determined by specified variables) which influence the individual customer.

\section{Acknowledgements}

The article was supported by student grant SGSDFJP 2015001.

\section{References}

[1] LUO, X., GRIFFITH, D. A., LIU, S. S., SHI, Y. Z.: The Effects of Customer Relationships and Social Capital on Firm Performance: A Chinese Business Illustration, J. of International Marketing, 12(4), 25-45, 2004, http://dx.doi.org/10.1509/jimk.12.4.25.53216.

[2] HORIBA, F.: Managing Knowledge Workers - New Skills and Attitudes to Unlock the Intellectual Capital in your Organisation, 1999 , Toronto: John Wiley \& Sons, ISBN 0471643181

[3] SVEIBY, K. E.: The New Organizational Wealth: Managing and Measuring Knowledge-based Assets, 1997, Barrett-Kohler: San Francisco, ISBN 1-57675-014-0.

[4] ESHGHI, A., HAUGHTON D., TOPI, H.: Determinants of Customer Loyalty in the Wireless Telecommunications Industry. Telecommunications Policy, 31(2), 93-106, 2007, DOI10.1016/j.telpol.2006.12.005.

[5] MORGANTI, E., DABLANC, L., FORTIN, F.: Final Deliveries for Online Shopping: The Deployment of Pickup Point Networks in Urban and Suburban Areas, Research in Transportation Business \& Management, July, 23-31, 2014, ISSN 22105395, DOI doi:10.1016/j.rtbm.2014.03.002.

[6] PRADHAN, R. P., ARVIN. M. B., NEVILLE, N., BELE, S. K.: Economic Growth and the Development of Telecommunications Infrastructure in the G-20 Countries: A Panel-Var Approach, Telecommunications Policy, 38(7), 634-649, 2014, doi:10.1016/j. telpol.2014. 03.001.

[7] FRANCISCO, M., WILLIAM, F., JAY, B.: Information Technology and Sustained Competitive Advantage: A Resource-Based Analysis. MIS Quarterly, 19(December), 487-505, 1995, ISSN 2162-9730, DOI 10.2307/249630.

[8] HAUCAP, J.: Editorial: Consumer behavior and telecommunications policy. Telecommunications Policy, 39(8), 625-626, 2015, DOI:10.1016/j.telpol.2015.07.013. 
[9] LA PAZ, A., RAMAPRASAD, A., SYN, T., VASQUEZ, J.: Editorial: An Ontology of E-Commerce - Mapping a Relevant Corpus of Knowledge, J. of Theoretical and Applied Electronic Commerce Research, 10(2), 1-9, 2015, DOI 10.4067/S0718-18762015000200001.

[10] ZHAO, H., MORAD, B.: From e-commerce to Social Commerce: A Close Look at Design Features, Electronic Commerce Research and Applications, 12(4), 246-259, 2013, DOI 10.1016/j.elerap.2012.12.003.

[11] HAQUE, A., KHATIBI, A.: E-Shopping: Current Practices and Future Opportunities Towards Malaysian Customer Perspective. J. of Social Sciences, 1(1), 41-46, 2005, ISSN 1549-3652, DOI 10.3844/jssp.2005.41.46.

[12] HaQUE, A., SADEGHZADEH, J., KHATIBI, A.: Identifying Potentially Online Sales in Malaysia: A Study on Customer Relationships Online Shopping, J. of Applied Business Research, 22(4), 119-131, 2006, ISSN 0892-7626.

[13] VANHOOSE, D. D.: E-Commerce Economics, 2011, New York: USA, ISBN 978-0-415-77897-8.

[14] DIEKE, A., HILlEBRAND, A., JOYCE, C., NIEDERPRUM, A.: Design and Development of Initiatives to Support the Growth of E-commerce via better Functioning Parcel Delivery Systems in Europe, 2014, WIK-Consult: Bad Honnef, ISBN 978-92-79-35322-2, DOI 10.2780/29929.

[15] BURKL, R.: Consumer Climate Significantly Improves Across Europe. GfK SE, Nuremberg, Retrieved October 15, 2015, from https:// www.gfk.com/news-and-events/press-room/press-releases/pages/consumer-climate-significantly-improves.aspx.

[16] FISHBEIN, M., AJZEN, I.: Belief, Attitude, Intention and behavior: An Introduction to Theory and Research, Reading, Massachusetts, Addison-Wesley, 1975, ISBN 0-201-02089-0.

[17] FISHBEIN, M., AJZEN, I.: Attitudes and Voting behaviour: An Application of the Theory of Reasoned Action, Progress in Applied Social Psychology, 1, 95-125, 1981, ISBN 0471279544.

[18] AJZEN, I.: The Theory of Planned Behavior. Organizational Behavior and Human Decision Processes, 50(2), 179-211, 1991, ISSN 0749-5978, DOI 10.1016/0749-5978(91)90020-T.

[19] MADDEN, T. J., ELLEN, P. S., AJZEN, I. A.: Comparison of the Theory of Planned behavior and the Malaysian Customer Perspective, J. of Social Sciences, 1(1), 41-46, 1992, ISSN 1549-3652, DOI 10.3844/jssp.2005.41.46.

[20] ORBELL, S., HODGKINS, S., SHEERAN, P.: Implementation Intentions and the Theory of Planned behavior. Personality and Social Psychology Bulletin, 23(9), 945-954, 1997, ISSN 01461672, DOI 10.1177/0146167297239004.

[21] RANDALL, D. M.: Why Students Take Elective Business Ethics Courses: Applying the Theory of Planned behavior, J. of Business Ethics, 13(5), 369-378, 1994, ISSN 0167-4544, DOI 10.1007/BF00871764.

[22] SHEPPARD, B. H., HARTWICK, J, WARSHAW, P. R.: The Theory of Reasoned Action: A Meta-Analysis of Past Research with Recommendations for Modifications and Future Research, J. of Consumer Research, 15(3), 325-43, 1988, ISSN 0093-5301, DOI $10.1086 / 209170$.

[23] VALlERAND, R. J., DESHACES, P., CUERRIER, J., PELLETIER, L. G., MONGEAU, C.: Ajzen and Fishbein's Theory of Reasoned Action as Applied to Moral behavior: A Confirmatory Factor Analysis, J. of Personality and Social Psychology, 62(1), 98-109, 1992, DOI 10.1037/0022-3514.62.1.98.

[24] MONTANO, D. E., KASPRZYK, D.: The Theory of Reasoned Action and the Theory of Planned behavior, In K. Glanz, F. M. Lewis, \& B. K. Rimer (Eds.), Health behavior and health education: Theory, research and practice (pp. 67-98), ISBN-13: 9780787996147.

[25] FALAGAS, M. E., ZARKADOUliA, E.: Factors Associated with Suboptimal Compliance to Vaccinations in Children in Developed Countries: A Systematic Review. Current Medical Research and Opinion, 24(6), 1719-1741, 2008, ISSN 0300-7995, DOI $10.1185 / 03007990802085692$.

[26] MILLS, E., JADAD, A. R., ROSS, C., WILSON, K.: Systematic Review of Qualitative Studies Exploring Parental Beliefs and Attitudes Toward Childhood Vaccination Identifies Common Barriers to Vaccination, J. of Clinical Epidemiology, 58(11), 10811088, 2005, ISSN 0895-4356, DOI: 10.1016/j.jclinepi.2005.09.002.

[27] ECOMMERCE EUROPE: European B2C E-commerce Report 2015, Retrieved October 18, 2015, from https://www.ecommerceeurope.eu/facts-figures/free-light-reports. 